\title{
Construction of a Transplantable Tissue-Engineered Artificial Peritoneum
}

\author{
H. Kuga ${ }^{a} \quad$ T. Morisakia $^{a}$ K. Nakamura ${ }^{a} \quad$ H. Onishia $\quad$ T. Matsuda ${ }^{b} \quad$ K. Sueishic \\ M. Tanaka ${ }^{\mathrm{d}}$ M. Katano ${ }^{\mathrm{a}}$ \\ Departments of a Cancer Therapy and Research, ${ }^{b}$ Biomedical Engineering, ${ }^{c}$ Pathophysiological and \\ Experimental Pathology, and dSurgery and Oncology, Graduate School of Medical Sciences, Kyushu University, \\ Fukuoka, Japan
}

\section{Key Words}

Artificial peritoneum, transplantable - Mesothelial cell · Fibroblast - Type-I collagen - Artificial connective tissue • Adhesion

\begin{abstract}
Background: Peritoneal defects lead to serious postoperative problems. Thus the development of physiological material to cover peritoneal defects is very desirable. Aim: The aim of this study was to develop a transplantable artificial peritoneum. Method: The artificial peritoneum consisted of collagen gel, fibroblasts, and mesothelial cells, and histological features were analyzed. The artificial peritoneum at the site of a peritoneal defect in the rat was transplanted to the abdominal wall. Results: Histological examination revealed that the artificial peritoneum consisted of a flat mesothelial monolayer upon a stromal matrix. All transplanted artificial peritoneums adapted well to the host and prevented severe adhesion. Conclusion: Our artificial peritoneum may be a useful transplantable bioengineered material for repair of surgical peritoneal defects.
\end{abstract}

Copyright $\odot 2004$ S. Karger AG, Basel

\section{Introduction}

The peritoneum extends over the entire surface of the serosal cavity and over all internal organs. It provides a protective barrier and a low-friction interface for the free movement of organs. Functionally, it works as a barrier between the peritoneal cavity and the general circulation [1-4]. The peritoneum is made up of a mesothelial monolayer and sub-mesothelial connective tissue. Surface mesothelial cells play important roles in peritoneum; they transport, secret, and absorb various molecules, and produce extracellular matrices that make up the basement membrane [5-7].

Peritoneal defects caused by surgical procedures lead to serious postoperative problems such as adhesive ileus or female infertility [8-10]. Postsurgical adhesions occur in $67-93 \%$ of abdominal surgical patients and are a primary cause of postoperative small bowel obstruction [11, 12]. Precipitating factors for adhesion formation are peritoneal injury, foreign body reaction, inflammation, and tissue ischemia [13-15]. The development of a physiological material to cover peritoneal defects is very desirable. Several preventive strategies against peritoneal adhesion have been reported including mesothelial cell transplantation, application of fibrin glue, and a cover sheet of hyal-

Mitsuo Katano, MD

Department of Cancer Therapy and Research

Graduate School of Medical Sciences, Kyushu University

Fukuoka 812-8582 (Japan)

Tel. +8192642 6219, Fax +81926426221, E-Mail mkatano@tumor.med.kyushu-u.ac.jp 
uronate [11, 16-22]. However, these strategies do not adequately prevent severe adhesion between intra-abdominal organs and massive peritoneal defects. Thus, the construction of a transplantable, full-thickness peritoneal model is required.

We have developed a transplantable artificial peritoneum made up of a mesothelial monolayer and connective tissue. The study of our new artificial peritoneum can provide information about the pathophysiology of many diseases related to the peritoneum. We show that this peritoneum may be useful as a transplantable, bioengineered material to repair peritoneal surgical defects.

\section{Materials and Methods}

\section{Cells and Reagents}

TIG-1-20 (JCRB0501), a human embryonic pulmonary fibroblast cell line, was obtained from Human Science Research and Resource Bank (Osaka, Japan). After informed consent had been obtained, human mesothelial cells were isolated from human omental tissue collected from patients undergoing gastrectomy because of early gastric carcinoma. The cells were grown in tissue culture flasks in DMEM (Gibco BRL, Grand Island, N.Y., USA) for fibroblasts and RPMI-1640 (Gibco BRL) for mesothelial cells. All culture media were supplemented with $10 \%$ fetal calf serum (FCS; Gibco BRL) with $100 \mathrm{units} / \mathrm{ml}$ penicillin and $100 \mu \mathrm{g} / \mathrm{ml}$ streptomycin. Aqueous type-I collagen from cow tendon was purchased from Koken (Tokyo, Japan). The following monoclonal antibodies were used: anti-cytokeratin CAM5.2 antibody (Becton Dickinson, San Jose, Calif., USA); anti-vimentin V9 antibody (Dakopatts, Copenhagen, Denmark); anti-laminin antibody (Fuji Yakuhin Corp., Tokyo, Japan), and antifactor VIII antibody (Dakopatts).

\section{Isolation and Characterization of Mesothelial Cells}

Fresh omentums resected for gastrectomy were washed twice with $10 \mathrm{ml}$ of phosphate-buffered saline (PBS) and incubated in $5 \mathrm{ml}$ of trypsin-EDTA (Gibco BRL) for $5 \mathrm{~min}$ at $37^{\circ} \mathrm{C}$. The cell suspension was replenished with $10 \mathrm{ml}$ of $10 \%$ FCS-RPMI-1640 and centrifuged at 1,200 rpm for $10 \mathrm{~min}$. After centrifugation, the cell pellet was resuspended in $10 \mathrm{ml}$ of 10\% FCS-RPMI-1640 and seeded into $75-\mathrm{cm}^{2}$ tissue culture flasks. To determine the characteristics of isolated cells, immunohistochemical analysis was done. Cells were fixed with ethanol, incubated in antigen-retrieval solution $(\mathrm{pH} 6$ citrate buffer), and heated in a high-pressure steam sterilizer at $120^{\circ} \mathrm{C}$ for $20 \mathrm{~min}$. Slides were washed in PBS, and endogenous peroxidases were quenched in $3 \% \mathrm{H}_{2} \mathrm{O}_{2}$-methanol for $30 \mathrm{~min}$. First antibodies were applied, and incubations were done overnight at $4{ }^{\circ} \mathrm{C}$. After washing, Histofine Simple Stain MAX PO (Nichirei, Tokyo, Japan) was applied as a secondary antibody. Slides were incubated for 30 $\mathrm{min}$ at room temperature. Reaction sites were visualized with diaminobenzidine as the chromogen, and nuclei were counterstained with hematoxylin.

\section{Construction of Artificial Peritoneum}

To make a large, flat, thick artificial peritoneum, we used a tubular mold that was designed for making artificial vascular grafts (fig. 1a). This mold consists of an external and an internal glass vessel fixed coaxially at one end with a silicone tube. The inner diameter of this mold was $5.0 \mathrm{~mm}$ and the outer diameter was $15.0 \mathrm{~mm}$. Cultured fibroblasts were suspended in $5 \mathrm{ml}$ of $10 \%$ FCS-DMEM at $6 \times 10^{6}$ cells $/ \mathrm{ml}$ and mixed with $5 \mathrm{ml}$ of type-I collagen. This mixture was brought into the annulus between the sheath and the mandrel of the mold (fig. 1b). This mold was put into a $50-\mathrm{ml}$ tube filled with $10 \%$ FCS-DMEM and incubated at $37^{\circ} \mathrm{C}$ in a humidified atmosphere of $5 \% \mathrm{CO}_{2}$ in air. After 3 days, a contracted tubular collagen-fibroblast mixture (fig. 1c) was taken from the mold and flattened by cutting along the major axis of the contracted mixture (fig. 1d). The flat artificial connective tissue, consisting of fibroblasts and collagen, was placed on a type-I collagen-coated plate, and mesothelial cells $(2 \times$ $10^{6}$ cells $/ \mathrm{ml}$ ) were seeded onto the upper surface of the connective tissue (fig. 1e). The mesothelial cell-seeded connective tissue was incubated at $37^{\circ} \mathrm{C}$ for $30 \mathrm{~min}$ to attach the mesothelial cells to the connective tissue, and then complete medium was added gently. The peritoneal model was cultured for an additional 5 days to allow mesothelial cells to attain confluence. A representative artificial peritoneum is shown in figure $1 \mathrm{f}$.

\section{Histological Examination of Artificial Peritoneum}

For light microscopy, human artificial peritoneum was fixed with buffered formalin containing 10\% methanol and 4\% formaldehyde (Mildform, Wako, Osaka, Japan), embedded in paraffin, and cut into $5-\mu \mathrm{m}$-thick sections. Histological examination was done by staining with hematoxylin and eosin, and immunohistochemical analysis was done with the method described above.

\section{Scanning Electron Microscopy}

Human artificial peritoneum was fixed with $2 \%$ glutaraldehyde for $1 \mathrm{~h}$, rinsed in $125 \mathrm{~m} M$ phosphate buffer ( $\mathrm{pH} \mathrm{7.2)} \mathrm{for} 30 \mathrm{~min}$, and post-fixed in $2 \% \mathrm{OsO}_{4}$ for $1 \mathrm{~h}$. Then samples were dehydrated using an ascending ethanol series and embedded in t-butanol at $37^{\circ} \mathrm{C}$ for $30 \mathrm{~min}$. The blocks soaked in t-butanol were frozen at $-30^{\circ} \mathrm{C}$ and dried in a freeze dryer (Eiko Engineering, Ibaragi, Japan). The dried blocks were coated with osmium plasma coater NL-OPC80-SH (Nippon Laser and Electronics Lab., Aichi, Japan). The coated blocks were observed and imaged using a JSM-840A scanning electron microscope (JEOL Ltd., Tokyo, Japan).

\section{Construction of Rat Artificial Peritoneum}

This experiment was carried out according to the Guidelines for Animal Experiments in the Faculty of Medicine, Kyushu University. Six- to eight-week-old male WKA rats were used in this study. All surgical procedures were done under general anesthesia with ether. Mesothelial cells of rats were isolated from omentums as described above. Fibroblasts were isolated from rat skins. Pieces of shaved skin $(2 \times 2 \mathrm{~cm})$ were obtained and minced. Minced skin pieces were incubated on type-I collagen-coated dishes with $20 \mathrm{ml}$ DMEM and 10\% FCS at $37^{\circ} \mathrm{C}$ in a humidified atmosphere of $5 \% \mathrm{CO}_{2}$ in air. After 7 days of incubation, fibroblasts proliferated on the dish. The cells were detached with trypsin-EDTA and washed twice with $10 \%$ FCSDMEM. The cell pellet was resuspended in $10 \mathrm{ml}$ of $10 \%$ FCSDMEM, seeded into $75-\mathrm{cm}^{2}$ flasks, and incubated at $37^{\circ} \mathrm{C}$ in a humidified atmosphere of $5 \% \mathrm{CO}_{2}$ in air. The artificial rat peritoneum was prepared by the same procedure as artificial human peritoneum (fig. 1). 

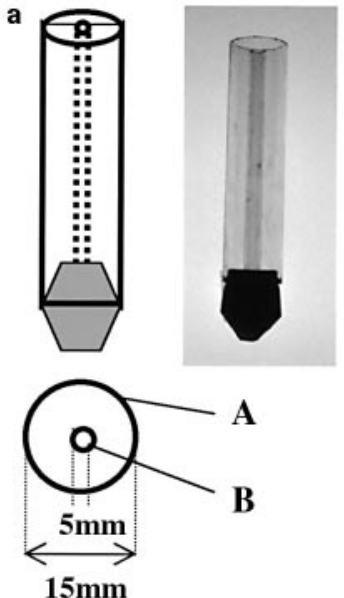

d

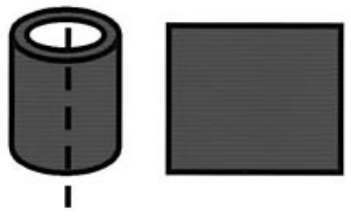

b

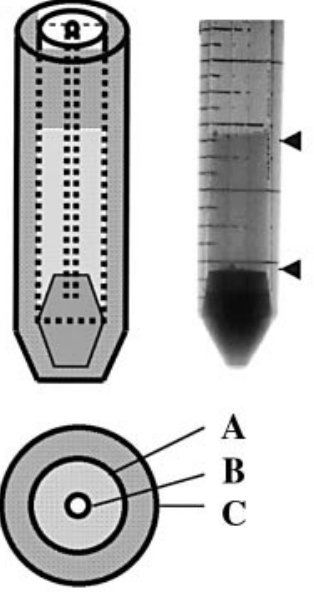

e

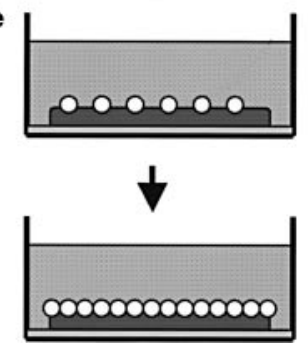

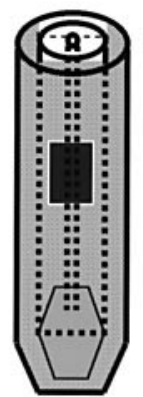
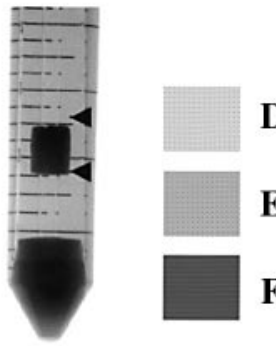

D

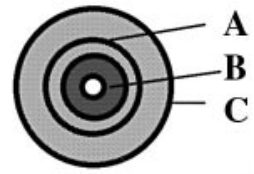

f

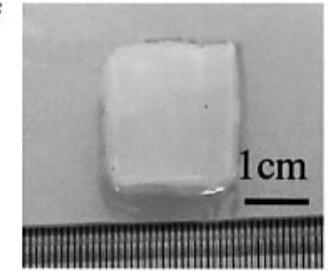

Fig. 1. Schematic and actual images of the artificial peritoneum. We used a tubular mold to make the artificial connective tissue. This mold consists of an external sheath and internal mandrel glass vessel (a). The type-I collagen-fibroblast mixture is poured into the tubular mold. This mold is then put into a 50-ml tube filled with complete medium (b). After 3 days, the collagen fibroblast mixture contracts and becomes the tubular artificial connective tissue (c). This tubular artificial connective tissue is cut along the major axis (d). Then, the artificial connective tissue is placed on a collagen-coated plate and mesothelial cells are seeded onto it (e, upper panel). After a 5-day incubation, surface mesothelial cells are confluent with the connective tissue (e, lower panel). f A macroscopic image of a complete artificial peritoneum $(2 \times 2 \mathrm{~cm}) . \mathrm{A}=$ External sheath; $\mathrm{B}=$ internal mandrel; $\mathrm{C}=50 \mathrm{ml}$ tube; $\mathrm{D}=$ type-I collagen-fibroblast mixture; $\mathrm{E}=$ $10 \%$ FCS-DMEM; F = contracted collagen-fibroblast mixture (artificial connective tissue).
Transplantation of Artificial Rat Peritoneum to Rats

Rats were shaved and disinfected with hypoethanol. Under general anesthesia, an incision was made through the midline of the abdomen. After laparotomy, two peritoneal defects $(1.0 \times 1.0 \mathrm{~cm})$ were made on the opposite side of the abdominal wall. An artificial rat peritoneum $(1.5 \times 1.5 \mathrm{~cm})$ was sewn in with $5-0$ synthetic absorbable sutures to cover one peritoneal defect, and the other defect was given no further treatment. The midline wound was closed with 2-0 nylon. The rats were maintained for 14 days with food and water.

\section{Assessment of Adhesions}

On the 14th postoperative day, rats were killed under anesthesia and the midline incision was reopened. Adhesion formation for each defect (with or without an artificial peritoneal transplant) was deter- mined macroscopically. We recorded type, area, and grade of the adhesion. The grades of adhesion were categorized as low, easily separated from the defect, and high, inseparable, requiring instruments for separation.

Histological Examinations of Transplanted Artificial Peritoneum

Both transplanted artificial peritoneums and abdominal walls involved in adhesions were resected en bloc with sufficient free margins for histopathological examination. Resected specimens were fixed in buffered formalin (10\% methanol, $4 \%$ formaldehyde) solution, embedded in paraffin, and cut into $5-\mu \mathrm{m}$-thick sections. Adhesive sites were examined carefully. In all transplanted artificial peritoneums, cell proliferation (mesothelial cells and fibroblasts), neovascularization, and inflammatory response against the transplanted materials were examined histopathologically. 


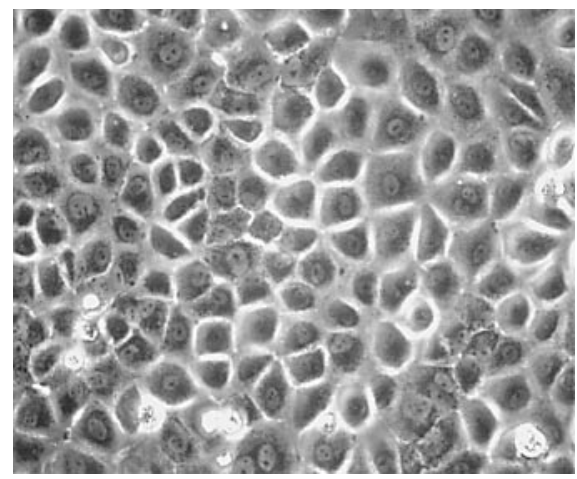

Fig. 2. Phase contrast image of human mesothelial cells isolated from omentum. Cells are polygonal and form a closed monolayer with a typical cobblestone pattern.

Fig. 3. Phase contrast surface (a) and interior (b) images of an artificial peritoneum. The surface of the artificial peritoneum has a cobblestone pattern of mesothelial cells (a). The deeper section of the artificial peritoneum consists of connective tissue with collagen and fibroblasts (b). HE-stained (c) and cytokeratin CAM5.2 immunohistochemically stained (d) paraffin sections are shown. A mesothelial monolayer upon the artificial connective tissue is seen. Scanning electron microscopy reveals surface mesothelial cells (e) with microvilli (right upper window). $\mathrm{m}=$ Mesothelial cell; $\mathrm{fb}=$ fibroblast .
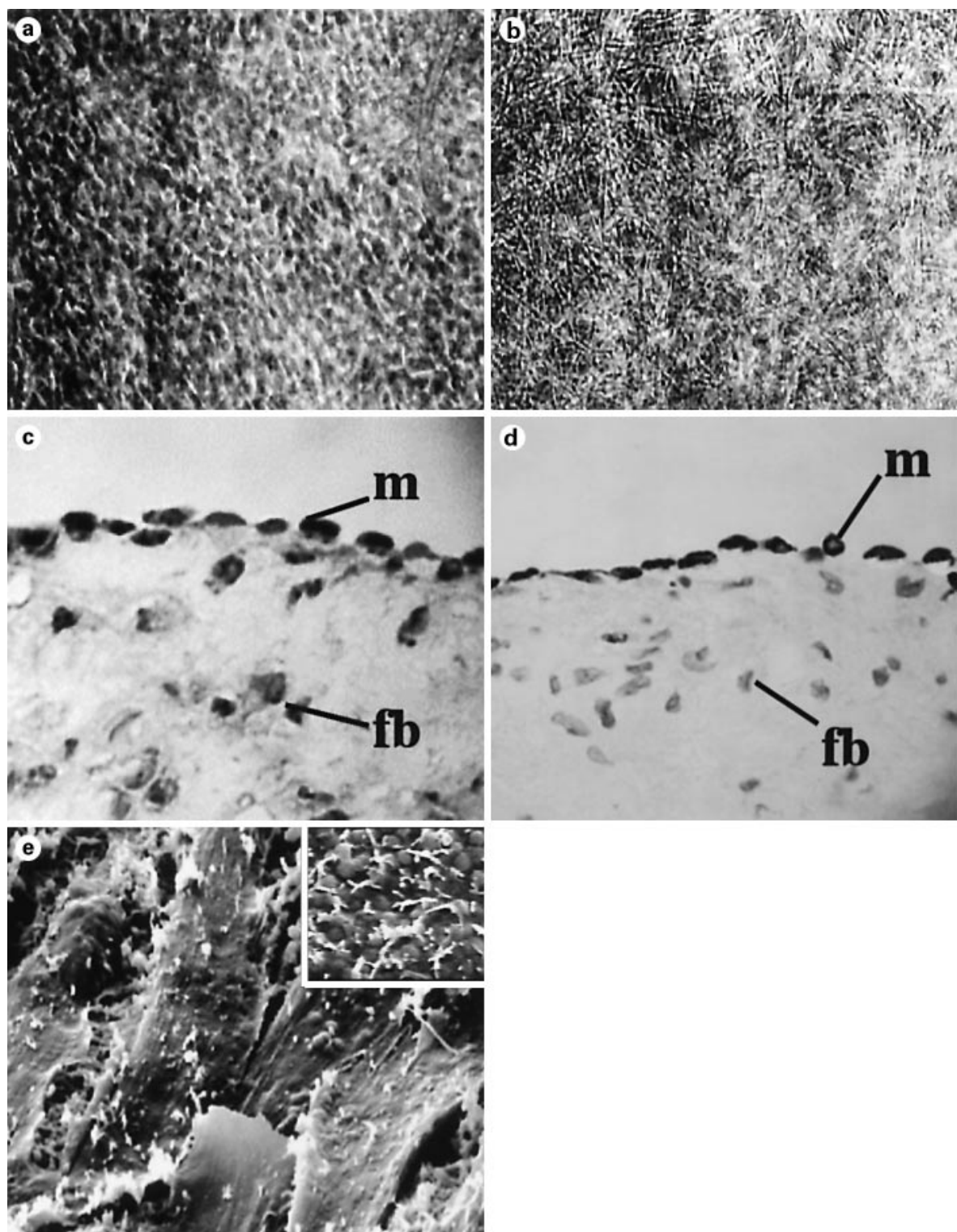

Statistical Analysis

Differences between treated and untreated control samples were analyzed with Student's t test, and $p<0.05$ was considered significant.

\section{Results}

Characterization of Mesothelial Cells

Mesothelial cells isolated from the omentum attached to a plastic plate within a few hours after plating and formed a closed monolayer with a typical cobblestone pattern after 5 days in culture (fig. 2). All cells reacted positively for cytokeratin, vimentin, and laminin but did not stain for factor VIII (table 1). Cells in the third passage were used for the experiments outlined below.

\section{Immunohistopathological Examination of Artificial \\ Human Peritoneum}

Phase contrast microscopy revealed that the artificial peritoneum consisted of surface cells with a cobblestone pattern (fig. 3a) on the artificial connective tissue that contained many fibroblasts growing within collagen lattices (fig. 3b). To confirm the monolayer characteristic of surface cells, paraffin-embedded sections of the peritoneum were examined microscopically. We found that the artificial peritoneum consisted of a single layer of highly 
Table 1. Characterizations of human omentum-derived mesothelial cells

\begin{tabular}{ll}
\hline Marker & $\begin{array}{l}\text { Immunohistochemical } \\
\text { staining }\end{array}$ \\
\hline Cytokeratin & + \\
Vimentin & + \\
Laminin & + \\
Factor VIII & - \\
\hline
\end{tabular}

Fig. 4. Transplantation of artificial peritoneum. Rat artificial peritoneums are transplanted to rat peritoneal defects (a). The macroscopic features of transplanted artificial peritoneums after 2 weeks show that they are well adapted to the host and that severe adhesion is not observed in any case (b). Microscopically, the transplanted artificial peritoneum is similar to rat peritoneal tissue (c transplanted artificial peritoneum; d normal rat peritoneal tissue). No significant immunological host reactions are seen in any of the transplanted artificial peritoneums, and neovascularization $(*)$ is observed in 12 of 15 transplanted peritoneums (e). $\mathrm{m}=$ Mesothelial monolayer; $\mathrm{ct}=$ sub-mesothelial connective tissue; $\mathrm{mu}=$ muscle of the host.
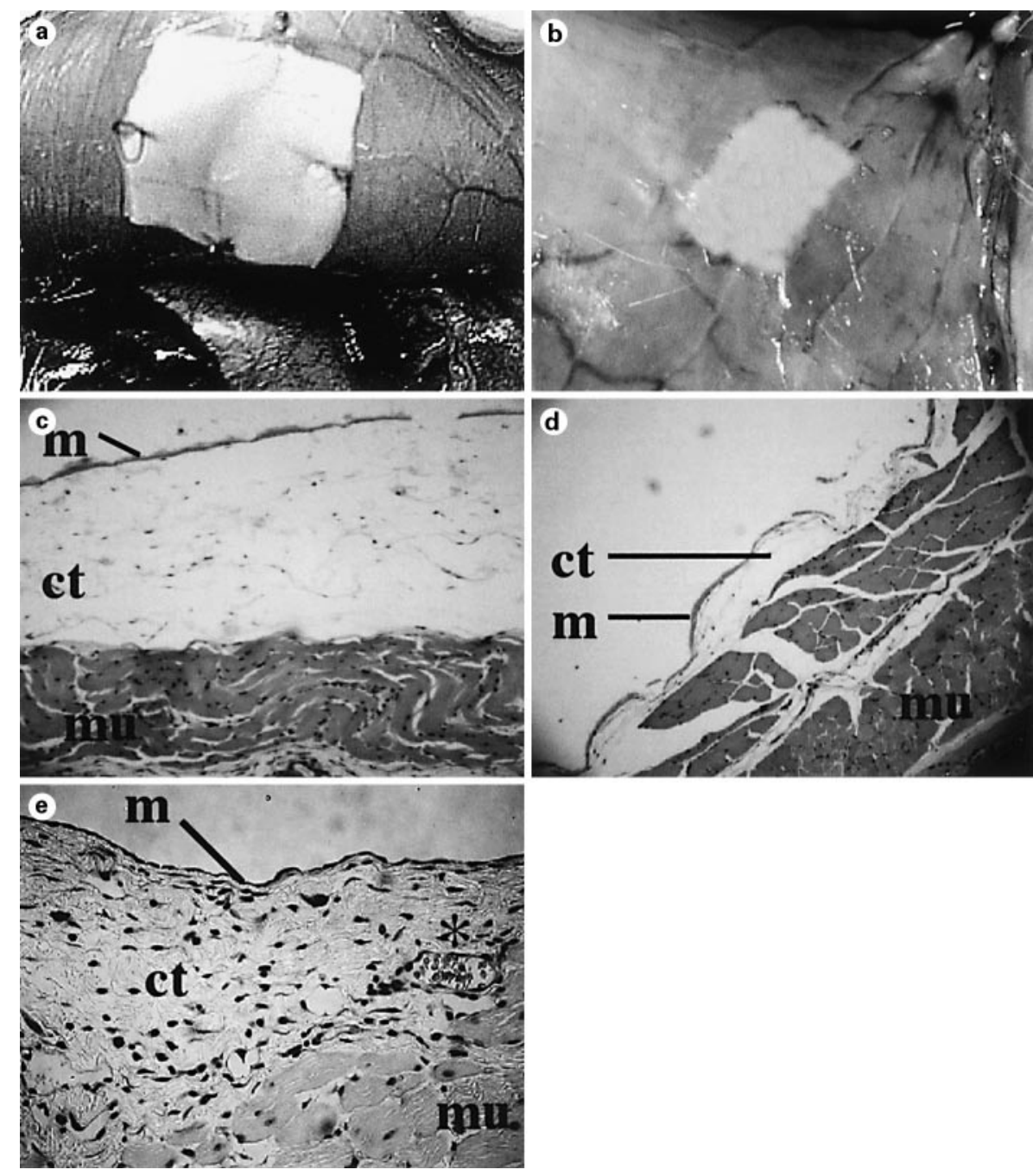

flattened cells riding over a collagen matrix containing fibroblasts. Invasion of surface monolayer cells into the matrix was not observed (fig. 3c). Immunohistochemical analysis confirmed the mesothelial characteristics of the surface monolayer cells because only surface cells reacted positively for cytokeratin CAM5.2 (fig. 3d). Scanning electron microscope images also supported the mesothelial characteristics of the surface monolayer cells. Surface monolayer cells were polygonal (fig. 3e), and microvilli were visible on the surfaces of cells (fig. 3e, inset).

\section{Transplantation Study}

We confirmed microscopically that artificial rat peritoneum consisted of surface monolayer cells on a collagen matrix containing fibroblasts (data not shown). All 15 peritoneal defects were covered successfully with artificial peritoneum (fig. 4a). All rats survived the transplantation study period. On day 14 , rats were sacrificed under general anesthesia and carefully examined macroscopically. All 15 transplanted artificial peritoneums adapted well to the normal peritoneum (fig. 4b). Transplanted artificial peritoneums were collected surgically and examined microscopically. The transplanted peritoneums had peritoneum characteristics. They consisted of a single layer of highly flattened cells on a collagen matrix containing fibroblasts (fig. 4c), and they had a close resemblance to normal rat peritoneum (fig. 4d). No noteworthy immunological host reactions, including mononuclear cell infiltration, against transplanted peritoneum were found (fig. 4e). Definite neovascularization in the transplanted peritoneums was found in 12 of 15 cases (fig. 4e). 
Fig. 5. Histological analysis of transplanted artificial peritoneum. Adhesions (arrowheads) in the no-treatment group are wide and severe (a). In the transplant group, adhesions are observed only at the edges of the transplanted artificial peritoneum, the adhesion areas are narrow, and the degrees of adhesions are slight $(\mathbf{b})$. aw $=$ Abdominal wall; $1=$ liver; $o=$ omentum; $a=$ artificial peritoneum.
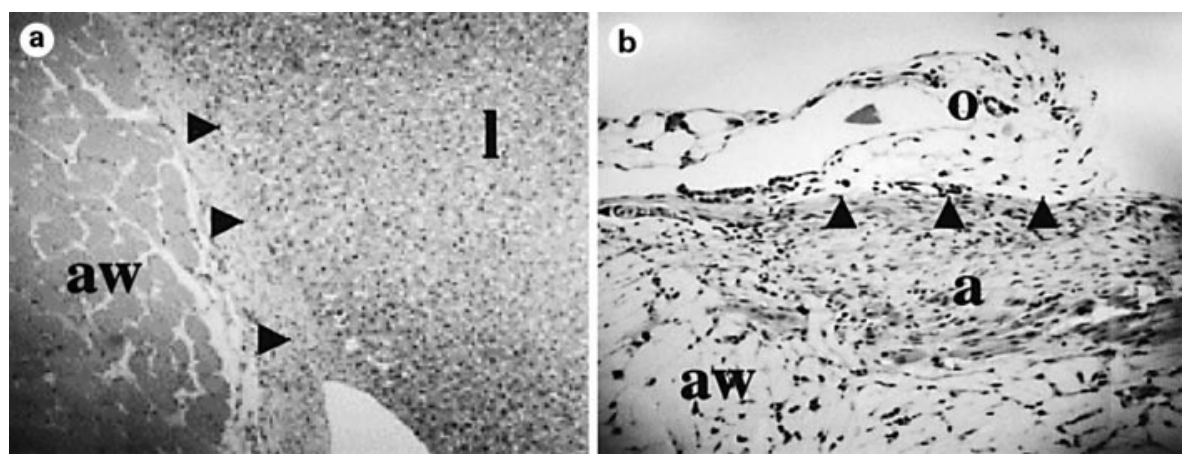

Table 2. Comparison of adhesions between the no-treatment and transplant groups

\begin{tabular}{|c|c|c|c|c|c|}
\hline \multirow{2}{*}{$\begin{array}{l}\text { Group } \\
\text { No treatment }(n=15)\end{array}$} & \multicolumn{3}{|c|}{ Type of adhesion } & \multirow{2}{*}{$\begin{array}{l}\begin{array}{l}\text { Area of } \\
\text { adhesion }\end{array} \\
-\end{array}$} & \multirow{2}{*}{$\begin{array}{l}\begin{array}{l}\text { Grade of } \\
\text { adhesion }\end{array} \\
-\end{array}$} \\
\hline & No adhesion & $10(66.7 \%)$ & & & \\
\hline & Omentum & $1(6.7 \%)$ & & $70 \mathrm{~mm}^{2}$ & high \\
\hline & Small bowel & $2(13.3 \%)$ & & $90 / 100$ & high \\
\hline & Liver & $2(13.3 \%)$ & & $100 / 100$ & high \\
\hline & \multicolumn{2}{|c|}{ Total adhesion rate $33.3 \%$} & mean & $92 \mathrm{~mm}^{2}$ & \\
\hline \multirow[t]{5}{*}{ Transplant $(n=15)$} & No adhesion & $10(66.7 \%)$ & & - & - \\
\hline & Omentum & $4(26.7 \%)$ & & $1 / 5 / 5 / 10 \mathrm{~mm}^{2}$ & low \\
\hline & Small bowel & $1(6.7 \%)$ & & 20 & low \\
\hline & Liver & $0(0 \%)$ & & - & - \\
\hline & \multicolumn{2}{|c|}{ Total adhesion rate $33.3 \%$} & mean & $8.2 \mathrm{~mm}^{2}$ & \\
\hline
\end{tabular}

High = Requiring instruments for separation; low = easily separated.

\section{Adhesion Prevention Study}

We judged the type, area, and grade of adhesions in each of the 15 rats (table 2). Five of 15 peritoneal defects without artificial peritoneum caused severe adhesions, including one to the omentum, two to the small bowel, and two to the liver. A representative picture of a highgrade adhesion is shown in figure 5a. Five of 15 peritoneal defects with transplantation of artificial peritoneum had low-grade adhesions (1 small bowel, 4 omentums). A representative picture of a low-grade adhesion between the omentum and the transplanted peritoneum is shown in figure $5 \mathrm{~b}$. No immunological reactions between the host and the transplanted peritoneum were found, even in specimens showing adhesion (fig. 5b). In the group without artificial peritoneums, the mean adhesion area was $92 \mathrm{~mm}^{2}$ in the 5 rats. In the group with artificial peritoneums, the mean adhesion area was $8.2 \mathrm{~mm}^{2}$ in the 5 rats.
Artificial peritoneum transplantation significantly reduced both the grade $(\mathrm{p}<0.001)$ and area $(\mathrm{p}<0.001)$ of adhesion (table 2).

\section{Discussion}

We developed a transplantable artificial peritoneum consisting of a single layer of mesothelial cells covering a collagen matrix containing many fibroblasts. All transplanted artificial peritoneums were well adapted to the host without significant immunological reactions. Transplanted artificial rat peritoneum significantly reduced both the grade and the mean area of adhesions between intra-abdominal organs and injured peritoneum.

Cell culture techniques that involve collagen gel have become increasingly popular over the last 10 years be- 
cause of their successful application to many different cellular systems and pathological processes [23, 24]. The application of these techniques in the current context has enabled us to develop an in vitro and transplantable human artificial peritoneum that closely resembles the physical and biochemical properties of in vivo tissue.

The biological properties of any cell are determined by its interaction with the extracellular matrix. Many extracellular proteins, including collagens types I, III and IV, fibronectin, and laminin can stimulate mesothelial proliferation [6].

In preliminary studies, we used various combinations of collagen types I and IV, laminin, and fibronectin as extracellular matrix. Type-I collagen alone appeared to support the rapid growth of mesothelial cells to form a confluent monolayer, provide a suitable matrix for fibroblast proliferation, and provide strength as transplantable material. In this study, we used only type-I collagen. It is difficult for making a large, flat, thick connective tissue. Culture of the collagen-fibroblast mixture on a dish resulted in irregular contraction and non-uniform shape and thickness. To overcome this problem, we used a mold designed for making artificial vascular grafts (fig. 1) [25]. This unique tool made it possible to produce large and flat artificial peritoneums. We were able to make $5-\mathrm{cm}^{2}$ patches of flat artificial peritoneum.

We transplanted artificial rat peritoneums onto rat peritoneal defects (fig. 3). Transplanted peritoneums adapted well in all cases without significant inflammatory reaction. Histopathological examination found neovascularization and fibroblast infiltration from the host (fig. 4). The artificial peritoneums significantly reduced the grade and area of adhesion. There was also a trend toward fewer bowel and solid organ adhesions (table 2).

Several approaches to preventing adhesion at a peritoneal defect have been reported, including administration of mesothelial cells [18], fibrin glue [8], or other agents [11]. Although our artificial peritoneum did not reduce the rate of adhesions, the adhesion of solid organs, which can cause severe problems such as ileus, was observed in only 1 case. In the other 4 cases of observed adhesions, omentums attached only to the edges of the transplanted artificial peritoneums and appeared to cause no complications. Our artificial peritoneum reduced the mean area of adhesions from 92 to $8.2 \mathrm{~mm}^{2}$ (table 2). Both the rate of adhesions to solid organs and the mean area of adhesions in our artificial peritoneums were less than those in the other reported methods $[8,11,18]$. Histological examination revealed that artificial peritoneum adapted to host tissue with neovascularization and caused no detectable inflammatory responses such as infiltration of mononuclear cells (fig. 4). Our reconstituted artificial peritoneum may be useful as an experimental peritoneal model. If autologous mesothelial cells and fibroblasts can be easily obtained, it may be a new covering material against a large peritoneal defect in future.

\section{Acknowledgements}

We thank Takaaki Kanemaru, Hiroshi Fujii, and Kaori Nomiyama for providing expert technical assistance. This work was supported by grants for General Scientific Research (14571143) from the Ministry of Education, Culture, Sports, Science, and Technology of Japan.

\section{References}

1 Niedbala MJ, Crickard K, Bernacki RJ: Adhesion, growth and morphology of human mesothelial cells on extracellular matrix. J Cell Sci 1986;85:133-147.

2 Andrews PM, Porter KR: The ultrastructural morphology and possible functional significance of mesothelial microvilli. Anat Rec 1973; 177:409-426.

3 Cunningham RS: The physiology of the serous membrane. Physiol Rev 1926;6:242-280.

4 Courtice FC, Simmonds WJ: Physiological significance of lymph drainage of the serous cavities and lungs. Physiol Rev 1954;34:419-448.

5 Slater NJ, Raftery AT, Cope GH: The ultrastructure of human abdominal mesothelium. J Anat 1989;167:47-56
6 Stylianou E, Jenner LA, Davies M, Coles GA, Williams JD: Isolation, culture and characterization of human peritoneal mesothelial cells. Kidney Int 1990;37:1563-1570.

7 Simionescu N: Cellular aspects of transcapillary exchange. Physiol Rev 1983;63:15361579.

8 Treutner KH, Bertram P, Lerch MM, Klimaszewski M, Petrovic-Kallholm S, Sobesky J, Winkeltau G, Schumpelick V: Prevention of postoperative adhesions by single intraperitoneal medication. J Surg Res 1995;59:764-771.

9 Menzies D: Peritoneal adhesions. Incidence, cause, and prevention. Surg Annu 1992;24:2745.

10 Menzies D, Ellis $\mathrm{H}$ : Intestinal obstruction from adhesions - How big is the problem? Ann R Coll Surg Engl 1990;72:60-63.
11 de Virgilio C, Elbassir M, Hidalgo A, Schaber B, French S, Amin S, Stabile BE: Fibrin glue reduces the severity of intra-abdominal adhesions in a rat model. Am J Surg 1999;178:577_ 580.

12 Ellis $\mathrm{H}$ : The cause and prevention of post operative intraperitoneal adhesions. Surg Gynecol Obstet 1971;133:497-511.

13 Moreno A, Aguayo JL, Zambudio G, Ramirez P, Canteras M, Parrilla P: Influence of abdominal incision on the formation of postoperative peritoneal adhesions: An experimental study in rats. Eur J Surg 1996;162:181-185.

14 Almdahl SM, Burhol PG: Peritoneal adhesions: Causes and prevention. Dig Dis 1990;8: 37-44. 
15 Moreno A, Aguayo JL, Zambudio G, Parrilla $P$ : Influence of different aetiological agents in the formation of postoperative peritoneal adhesions. Experimental study in rats. Dig Surg 1993;10:181-185.

16 de Virgilio C, Dubrow T, Sheppard BB, MacDonald WD, Nelson RJ, Lesavoy MA, Robertson JM: Fibrin glue inhibits intra-abdominal adhesion formation. Arch Surg 1990;125: 1378-1382.

17 Sheppard BB, de Virgilio C, Bleiweis M, Milliken JC, Robertson JM: Inhibition of intraabdominal adhesions: Fibrin glue in a long term model. Am Surg 1993;59:786-790.
18 Bertram P, Tietze L, Hoopmann M, Treutner $\mathrm{KH}$, Mittermayer C, Schumpelick V: Intraperitoneal transplantation of isologous mesothelial cells for prevention of adhesions. Eur J Surg 1999; 165:705-709.

19 Di Paolo N, Vanni L, Sacchi G: Autologous implant of peritoneal mesothelium in rabbits and man. Clin Nephrol 1990;34:179-184.

20 Lucas PA, Warejcka DJ, Zhang LM, Newman WH, Young HE: Effect of rat mesenchymal stem cells on development of abdominal adhesions after surgery. J Surg Res 1996;62:229_ 232.

21 Kramer K, Senninger N, Herbst H, Probst W: Effective prevention of adhesions with hyaluronate. Arch Surg 2002;137:278-282.
22 Greenawalt KE, Butler TJ, Rowe EA, Finneral AC, Garlick DS, Burns JW: Evaluation of sepramesh biosurgical composite in a rabbit hernia repair model. J Surg Res 2000;94:92-98.

23 Bell E, Ehrlich HP, Buttle DJ, Nakatsuji T: Living tissue formed in vitro and accepted as skinequivalent tissue of full thickness. Science 1981;211:1052-1054.

24 Yang EK, Seo YK, Youn HH, Lee DH, Park SN, Park JK: Tissue engineered artificial skin composed of dermis and epidermis. Artif Organs 2000;24:7-17.

25 Hirai J, Matsuda T: Self-organized, tubular hybrid vascular tissue composed of vascular cells and collagen for low-pressure-loaded venous system. Cell Transplant 1995;4:597-608. 